\title{
The Italian Hall Tragedy, 1913: A Hundred Years of Remediated Memories
}

\author{
Anne Heimo
}

On Christmas Eve 1913 seventy-three people were crushed to death during the 1913-1914 Copper Strike in the small township of Calumet on the Keweenaw Peninsula, Upper Michigan. On Christmas Eve the local Women's Auxiliary of the Western Federation of Miners (WFM) had arranged a party for the strikers' families at the local Italian hall. At some point in the evening someone was heard to shout 'fire' and as people rushed to get out of the building they were hauled down the stairs and crushed to death. Sixty-three of the victims were children. There was no fire. Later on this tragic event became to be known as 'The Italian Hall tragedy', 'The Italian Hall disaster' or the '1913 Massacre,' and it continues to be the one most haunting event in the history of the Copper Country.

As a folklorist and oral historian, I am foremost interested in the history and memory practices of so called ordinary people in everyday situations and how they narrate about the past and events and experiences they find memorable and worth retelling. When first hearing about the tragedy a few years ago, I could not help noticing that it had all the elements for keeping a story alive. The tragedy was a worker's conflict between mining companies and miners, which resulted in the death of many innocent people, mainly children. Although the tragedy was investigated on several occasions, no one was found responsible for the deaths, and the case remains unsolved to this day. Was it a pure accident, an ill-fated prank or the deliberate work of antitrade-unionists, in other words murder? The inquiries were carried out inadequately and the documents of the coroner's inquest went missing for a half century. Even the doors of the hall have an important part in the story. While some believe that the doors were bolted from the outside to stop people from fleeing, some are sure that the doors opened inward and could not be opened, because the bodies were piling up in the front of them. In many ways the story also reminds me of historical tales concerning so called Christmas panics in churches around Finland in the eighteenth and nineteenth century. These tales often include a false fire, people suffocating in stairways trying to flee and that many of the victims are children. These tales are based on 
historical events, and because of these panics, officials ordered, already in the nineteenth century, that church doors and doors of other public buildings are to open outward. ${ }^{1}$

Now after going through dozens and dozens of versions of the story I am perhaps even more amazed by its persistence. The story has been told so many times and on so many forums, that it is nearly impossible to write about it without quoting someone else's words. But why, a century later, do people continue to retell this particular story?

Previously I have examined narrated memories and historical interpretations mainly from the perspective of the never-ending social process of history making, in which we all take part regardless of our education, profession or motivation. ${ }^{2}$ This continuous process consists of the interplay of public, popular, and scholarly histories and takes into notice the active role of non-historians and vernacular history in history making. Although people have always participated in history and memory making, new information and communication technology enable people to engage in these practices in ways that were not possible before. This shift also offers new opportunities for scholars to examine these activities, which before the digital era happened mostly within small communities and groups and could not be easily observed without long-term participant observation and interviewing.

An alternative way to look at this same process is to examine it as the remediation of transnational and transcultural memory. First, a historical event is created by the media, '... by newspaper articles, newsreels, photographs, diaries, historiographic works, poems, novels, plays, paintings, memorials, films, TV series, comics and blogs as well as Twitter and Facebook status updates' as Dagmar Brunow points out. ${ }^{3}$ After this the memory of the event will continue to travel across and beyond different borders, scales and territories and have

1 Janne Toivonen, “'Kirkko pallaa, alttari puttoo ja kivimuuri kaatuu' - joulukirkkojen tuhoisien pakokauhujen vuoksi ovet aukeavat Suomessa ulospäin," Yle uutiset, 27 December 2015, accessed 16 June 2016, http://yle.fi/uutiset/kirkko_pallaa_alttari_puttoo_ja_kivimuuri_ kaatuu_joulukirkkojen_tuhoisien_pakokauhujen_vuoksi_ovet_aukeavat_suomessa_ ulospain/8533432.

2 See e.g. Anne Heimo, Kapina Sammatissa: Vuoden 1918 paikalliset tulkinnat osana historian yhteiskunnallisen rakentamisen prosessia (Helsinki: Suomalaisen Kirjallisuuden Seura, 2010), 17-18; Anne Heimo, "The 1918 Finnish Civil War Revisited: The Digital Aftermath," Folklore 57 (2014), 142, accessed 7 June 2016, doi:10.7592/FEJF2014.57.heimo.

3 Dagmar Brunow, Remediating Transcultural Memory: Documentary Filmmaking as Archival Intervention (Berlin/Boston: De Gruyter, 2015), 4. 
new meanings attached to it at every stage. ${ }^{4}$ When the memory ceases to be remediated it has lost its meaningfulness. The same applies to all narratives. When we can no longer find meaning in a narrative, there is no point in retelling it.

Our everyday life has changed fundamentally during the last few decades. Internet technology has had a huge impact on many aspects of our lives, among them the possibility to take part in global activities, which transcend national borders. In memory studies this shift has led to the re-examining and contesting of former notions of memory, for instance the terms collective memory and national memory, which perceive groups, communities or the nation-state as certain types of containers of memory with more or less clear-cut borders. Even private and personal memories are increasingly shared in public with people whom we do not necessarily know. To overcome the problems associated with these former terms, terms like transnational memory ${ }^{5}$ and transculturalmemory ${ }^{6}$ have been introduced. Both of these terms stress the movement of memory across and between times, places, generations and media, from the private sphere to the public sphere, from individuals to communities and vice versa and beyond national (and other) borders. Additionally the acknowledging of the role of (new) media in the construction of memory has led to a shift from studying 'sites of memory' to the 'dynamics', 'flows' and 'travels' of memory. ${ }^{7}$ While an image may travel and be given new meanings without being altered, memories in narrative form will always be subject to change, and be shaped and reworked to new needs. This shaping is done according to the requirements of popular storytelling and draws on knowledge and information from the surrounding culture.

4 Chiara De Cesari and Anne Rigney, "Introduction: Beyond methodological nationalism," in Transnational Memory: Circulation, Articulation, Scales, ed. Chiara De Cesari and Anne Rigney, (Berlin/Boston: De Gruyter, 2014), 9.

5 De Cesari and Rigney, "Introduction," 3-8.

6 Astrid Erll, "Travelling Memory," Parallax 17 (2011), 9, accessed 7 June 2016, doi:10.1080/135346 45.2011.605570.

7 José Van Dijck, Mediated Memories in the Digital Age, (Palo Alto, CA: Stanford University Press, 2007), 18-19, 53-55; Astrid Erll and Ann Rigney," Introduction: Cultural Memory and its Dynamics," in Mediation, Remediation, and the Dynamics of Cultural Memory, ed. Astrid Erll and Ann Rigney, (Berlin/Boston: De Gruyter, 2009); Julia Creet, "Introduction," in Memory and migration: multidisciplinary approaches to memory studies, ed. Julia Creet and Andreas Kitzmann, (Toronto: University of Toronto Press, 2011), 9; Erll, “Travelling Memory,” 9; De Cesari and Rigney, "Introduction," 8-11. 
'New' media is often considered more democratic than 'old' media, although this is not always the case. ${ }^{8}$ It is also true that most users will rather passively follow the activities of other users or share contents created by others on the Internet than create new contents themselves. ${ }^{9}$ Nonetheless, I think that the examining of history and memory making practices online will give insight to these practices and demonstrate what people themselves find worth remembering of their past and why.

\section{Everyday Practices of Online History and Memory Making}

The Internet is full of both large institutional and small-scale private sites of memory and commemoration, which are used increasingly to showcase lost heritage sites, to commemorate historic events retrospectively or to share family memories with both local and transnational audiences. Although collaboration and participation with wider audiences is common practice among public historians working in archives, museums or oral history projects as well as a wide range of other actors, including writers, journalists, artists, film makers and activists, people will often choose to act individually on the personal level and share their memories spontaneously with their peers rather than take part in institutionally organized acts of memorialization, however impressive or well-planned they may be. ${ }^{10}$ They can become their own publishers, authors and archivists, who do not necessarily need or want expert supervision to create, manage and curate their collections. At the same time these practices result in a new kind of heritage, which is produced without outside supervision or expertise and which is more liable to change than preservation. ${ }^{11}$

See e.g. Joanne Garde-Hansen, Andrew Hoskins and Anna Reading, "Introduction", in Save as...Digital Memories, ed. Joanne Garde-Hansen, Andrew Hoskins and Anna Reading, (London \& New York: Palgrave McMillan, 2009), 8-11; Jose Van Dijck, The Culture of Connectivity: A Critical History of Social Media, (Oxford: Oxford University Press, 2013).

9 Jakob Nielsen, "The 9o-9-1 Rule for Participation Inequality in Social Media and Online Communities," Nielsen Norman Group, 2006, accessed 7 June 2016, https://www.nngroup .com/articles/participation-inequality/.

10 Peter Jan Margry and Cristina Sánchez-Carretero, "Introduction: Rethinking Memorialization: The Concept of Grassroots Memorials," in Grassroots Memorials. The Politics of Memorializing Traumatic Death, ed. Peter Jan Margry and Cristina Sánchez-Carretero, (New York \& Oxford: Berghahn, 2011), 3-4; Heimo, The 1918 Finnish Civil War Revisited.

11 Elisa, Giarccardi, "Introduction: Reframing Heritage in Participatory Culture," in Heritage and Social Media: Understanding Heritage in a Participatory Culture, ed. Elisa Giarccardi, 
Participatory culture and grassroots activities are characteristics of many of these practices. Web 2.0 is often regarded a particular technology which makes interaction on the Internet (social media) possible, when it actually refers more to the way people are using the Internet than to the actual technology. ${ }^{12}$ This new mindset includes, for instance, a motivation to participate and share, to trust other users and the right to create new contents by remixing former ones, which are all features of convergence and participatory culture. Convergence refers to the circulation of media due to technological, industrial, cultural and social changes in culture and to the flow of contents across multiple media platforms. Participatory culture highlights community involvement and is ready to offer all interested an opportunity to contribute. Participatory culture is not only about production and consumption; it is also about affiliation, expression, collaboration, distribution and the disclaiming of former divisions between professionals and amateurs. ${ }^{13}$ Although participatory culture is neither only a feature of today, nor exists only on the Internet, the term is now commonly used when referring to cultural practices on the Internet. These practices may also occur offline, but are still dependent on new technology, and the creations can be distributed globally through digital networks even when they are produced personally and locally. ${ }^{14}$

The Italian Hall tragedy offers a fruitful example to examine the remediation of transcultural memory across and between different kinds of borders and times. The tragedy was immediately covered by local and national media from dissenting vantage points and photos of the site of the tragedy, the victims and their funerals, were circulated widely. However, a year later there was little or no mention of the event in public, and this is how the situation remained for decades. Even the release of Woody Guthrie's song '1913 Massacre' in 1941 did not break the silence. Nonetheless the memory of the tragedy continued to be conveyed, especially amongst those families and local ethnic

(London \& New York, Routledge, 2012), 1-10; See also Laurajane, Smith, Uses of Heritage, (Oxon, Routledge, 2006).

12 Timothy O'Reilly, "What is Web 2.o? Design Patterns and Business Models for the Next Generation of Software," Oreilly (2005), accessed 7 June 2016, http://www.oreilly.com/ pub/a/web2/archive/what-is-web-2o.html.

13 Henry Jenkins, Convergence Culture: Where Old and New Media Collide, (New York \& London: New York University Press, 2006), 2-3, 322-331; Henry Jenkins, Sam Ford and Joshua Green, Spreadable Media: Creating Value and Meaning in a Networked Culture, (New York \& London: New York University Press, 2013).

14 Joanne Garde-Hansen, Media and Memory, (Edinburgh: Edinburgh University Press, 2011), 46. 
communities which had been affected by the tragedy. When the time came, these memories surfaced again and have since been remediated in numerous ways and for various reasons. Whereas these private and personal memories used to be mostly presented and published by outsiders, such as journalists, historians and writers, today the situation is quite different. People can now share their memories on web and social media sites by themselves, without supervision. This case study also shows that over a century later the memory of the tragedy is still open for new interpretations and uses.

In the following I will first introduce Calumet, its history and multi-ethnic community and the actual tragedy. Then I will examine the memory of the tragedy from different perspectives, including the remediated memory and the transnationality and diasporic nature of the heritage site. After this I will present some examples of online commemoration and explore some of the reasons why the memory of the tragedy continues to fascinate and intrigue people.

\section{Calumet - A Multi-Ethnic Mining Community}

Copper Country was the home of the first mining boom in the United States. Copper was found on the Upper Michigan Peninsula in the 1840 and from then on, for over a century, the area was in need of a constant flow of immigrant workers. Most of the mining companies were relatively small in size and employed only a few thousand workers at the most. One of the largest mining companies was Calumet \& Hecla (C\&H), which had over 21,00o employees in 1907. Like so many other companies, also $\mathrm{C} \& \mathrm{H}$ applied a paternalistic system and built houses, shops, schools, libraries and other services for its employees. In addition to serving the needs of the company's workers, paternalism also meant that the company had control over nearly all aspects of the lives of its employees. ${ }^{15}$

From the 186os to 1920 s over 350,000 Finns immigrated to North America. In the United States large numbers of Finns ended up working in the mines in

15 Gary Kaunonen and Aaron Goings, Community in Conflict: A Working-Class History of the 1913-14 Michigan Copper Strike and the Italian Hall Tragedy, (Lansing: Michigan State University Press, 2013), 21-24, 85; Linsday E. Hiltunen, Cultural Memory and the Power of Place: One Hundred Years of Remembering the Italian Hall Tragedy and the 1913-1914 Michigan Copper Strike, (Macomb: Faculty of the Department of History of Western Illinois University, 2014), 25, accessed 7 June 2016, http://gradworks.umi.com/15/57/1557255.html. 
Copper Country in Michigan and the Iron Range in Minnesota. One of the first permanent Finnish settlements in the United States was founded in Calumet already in the 1860s and in the following decades Finns continued to move there. ${ }^{16}$ The Finnish community was only one of the many immigrant communities in the region at the time, but it was and still is the most populous ethnic community there.

Around the turn of the century socialism began to gain ground among Finnish immigrants and many 'Red Finns' took an active role in leftist politics and trade unions. ${ }^{17}$ This made the Finns the largest socialist group in the country and one of the most discriminated. All around the United States workers were forced to compete against each other, which lead to ethnic hostilities. While immigrants from English-speaking countries, Germans and Scandinavians were offered high-rank jobs, Finns, Slavs and Italians were given the most menial jobs. The differentiation between the different ethnic groups was about 'old' and 'new' immigrant groups, but it was also about racial ideology. Contrary to Scandinavians the whiteness of Finns was questioned. ${ }^{18}$

Despite the fact that Copper Country workers had been joining trade unions since the 1880 , the WFM-organized Copper Country Strike in 1913-1914 was the first major strike in the area. The strike was a multiethnic enterprise to improve working conditions, achieve union recognition and to unite immigrant communities. Many Finns were involved in the strike, both as members of the local WFM or because they held positions within the WFM. The strike began on 23 July 1913 and ended nine months later in April, 1914. The strike was not a success for the strikers, and thousands of miners moved elsewhere afterwards. ${ }^{19}$ Nonetheless, mining continued until the 196os when most of the mines were shut down in the area. The very last copper mine was shut down in 1995 .

16 Peter Kivisto, Immigrant Socialists in the United States: The Case of the Finns and the Left, (London and Toronto: Associated University Press, 1984), 72, 74-75.

17 Kivisto, Immigrant Socialists in the United States, 92-98; Ralf Kauranen and Mikko Pollari, "Transnational socialist imagination: The connections between Finnish socialists in the USA and Finland at the turn of the 2oth century," in Labouring Finns: Transnational Politics in Finland, Canada, and the United States ed. Michel S. Beaulieu, Ronald N. Harpelle and Jaimi Penney, (Turku: Institute of Migration, 2011); Kaunonen and Goings, Community in Conflict, 49-51.

18 Kivisto, Immigrant Socialists in the United States, 126-129; Kauranen and Pollari, "Transnational socialist imagination," 40-41; Kaunonen and Goings, Community in Conflict, 47-48.

19 Kivisto, Immigrant Socialists in the United States, 139; Kaunonen and Goings, Community in Conflict, 88-91, 113-114. 


\section{The Italian Hall Tragedy}

The Copper Country Strike had been going on for five months and to cheer the families and especially the children of the strikers, the Women's Auxiliary Organization of the WMF decided to arrange a party at the Italian Hall on Christmas Eve. Five to seven hundred people, a major part of them local children, were at the party enjoying themselves, when a shout of 'fire' was heard. Only a moment later people began to rush towards the stairs to get out. Tens of people found their way out, but then someone fell down the steep stairway. This caused more people to tumble down the stairs and people began to pile up on top of each other. Help arrived in a few minutes, but it took hours until people could be entangled from each other and moved from the staircase. Some of them survived with no or minor injuries, but seventy-three people were found dead. Most of the dead were children of Finnish immigrants. The victims were buried a few days later at the local Lakewood cemetery, side by side in two unmarked mass graves, one for twenty-two catholic victims and one for the forty-four protestant ones. The rest of the victims were buried in family graves. Burial and memorial services were held in six churches in several languages, with the Finnish Church among them. ${ }^{20}$

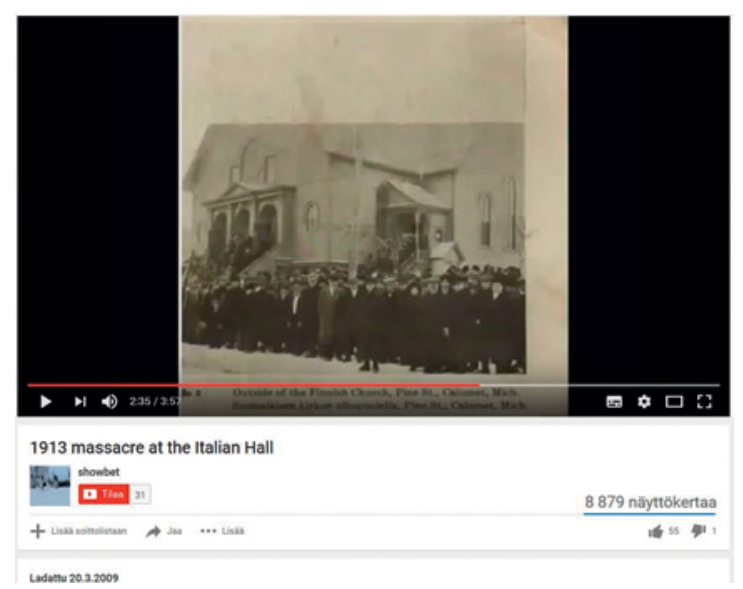

FIGURE 11.1 [s] [ ] clippings from local newspapers. Family and friends of Finnish victims held their funeral service at the local Finnish church.

(Accessed 1oJune, 2016, https://www.youtube .com/watch? $v=U g r P K 2 C N u J g$. Screenshot 4 May 2017)

20 Steve Lehto, Death's Door: The Truth behind Michigan's Largest Mass Murder, (Troy, MI: Momentum Books, 121-123; Hiltunen, Cultural Memory and the Power of Place, 119-120. 
Several eyewitnesses testified that a strange man wearing an anti-union Citizen Alliance button pinned to his coat had run up the stairs and shouted 'fire' and then left, but this was never officially stated. The mining companies denied having anything to do with the incident. Neither the coroner's inquest held soon after the tragedy nor the subcommittee sent by the United States Congress to investigate the tragedy a few months later found anyone guilty for the deaths. ${ }^{21}$ This led to several alternative explanations concerning the cause of the disaster. Some blamed the tragedy on a drunkard who had thought he had seen flames and some on a linguistic misunderstanding since most of the people in the hall did not share a common language. ${ }^{22}$ According to the current predominant version, which is largely based on Steve Lehto's investigations, the mining companies had wanted to disturb the party, but there is no evidence that they had actually bolted the doors or that they had planned the deed with its horrific outcome. ${ }^{23}$

For decades the doors were not considered to have anything to do with the tragedy, but at some point they became one of the main motives of the story. Some are sure that the outward opening doors had been deliberately bolted by members of the Citizen's Alliance to keep people inside, while others maintainthat the bodies piling up in front of the doors made it impossible to open the inward opening doors although documents prove that the doors did not open inward. ${ }^{24}$ In October 2015 Steve Lehto posted a newspaper clipping on the Facebook page 'The Italian Hall Disaster - Resource Center' to prove once more his point about the doors having nothing to do with the causalities. One person commented on his post: 'That's all I ever here [sic] too is about the doors. I tell them that you said the doors opened the right way and even tell them the way the staircase was they couldn't have opened in. They still don't believe me. Ugh. It's no use. LOL.'

21 Lehto, Death's Door, 124-152, 163-174.

22 Hiltunen, Cultural Memory and the Power of Place, 81; Raymond Alvar Wargelin, "Response" to Puotinen, Arthur, "Copper country Finns and the strike of 1913," in The Finnish Experience in the Western Great Lakes Region: New Perspectives, ed. Michael G. Karni, Matti E. Kaups and Douglas J. Ollila, (Turku: Migration Institute, 1975), 154.

23 Lehto, Death's Door, 207-208; Steve Lehto, Italian Hall: The Official Transcript of the Coroner's Inquest, (Troy, MI: Momentum Books, 2007).

24 Lehto, Death's Door, 175-178. Facebook, "The Italian Hall Disaster - Resource Center", accessed 10 June 2016, https://www.facebook.com/pg/The-Italian-Hall-Disaster-ResourceCenter-291845417514549/notes/?ref=page_internal. 


\section{Remediated Memories of the Italian Hall Tragedy}

The news about the tragedy at the Italian Hall was first released by the Finnish-American socialist newspaper Työmies (Worker), which published an extra edition on Christmas Day in both Finnish and English. The paper announced the death toll to be 80 and already at this stage it referred to eyewitness accounts concerning a strange man with his cap pulled down over his eyes and a Citizen's Alliance button pinned to the lapel of his coat yelling 'fire' before leaving the building. On 26 December the Työmies declared on its front page ' 83 murhattu!' ( 83 murdered!) and accused capitalists for the murder of children. The next day the first members of the staff of Työmies were arrested for their accusations. ${ }^{25}$ The news soon circulated throughout the country and abroad. Some newspapers took a neutral stance, but many sided either with or against the strikers and WFM.

A year later many had put the event behind them. On the first anniversary of the tragedy there was no mention of it in the local newspapers. The situation stayed the same for years to come. For example, in 1920 Juuso Hirvonen wrote a 120-page history of the Finns in Copper Country, but did not mention the tragedy and only briefly referred to the strike. ${ }^{26}$ The first to break the silence was Ella Reeves Bloor, one of the members of the Women's Auxiliary Organization, who had arranged the Christmas party at the Italian Hall. ${ }^{27}$ It was her autobiography which inspired Woody Guthrie to compose his song '1913 Massacre' on his album Struggle, a year later, in 1941. ${ }^{28}$ Others have also recorded the song, among them Bob Dylan who wrote his own version of the song “'Song for Woody', as a tribute to Guthrie in 1961, and Arlo Guthrie, who recorded his father's version in 1972. But in the local community the memory remained hushed and discussed only among friends and family. ${ }^{29}$

The silence was finally broken in the 1970s when the plans to tear down the Italian Hall made people alert to the possibility of losing an important local

\footnotetext{
25 Lehto, Death's Door, 110.

26 Juuso Hirvonen, Michiganin kuparialue ja suomalaiset siirtolaiset, (Duluth: Privately published, 1920).

27 Ella Reeve Bloor, We Are Many: An Autobiography of Ella Reeve Bloor, (New York: International Publishers, 1940).

28 Hiltunen, Cultural Memory and the Power of Place, 19.

29 See e.g. Lehto, Death's Door, 2; Hiltunen, Cultural Memory and the Power of Place, 15.
} 
site of memory. ${ }^{30}$ Several local stories and memoirs of the tragedy were published in the 1980s. ${ }^{31}$ A new wave of books came in the 2000s. ${ }^{32}$ Among them Deborah K. Frontiera's young adult novel Living on Sisu, which tells the story through the diary entries of a 12-year old girl. ${ }^{33}$ In 2006 attorney and author Steve Lehto published his book Death's Door: The Truth behind the Italian Hall Disaster and the Strike of $1913 .{ }^{34}$ Lehto's aim was to set the record straight so he also published the transcript of the trial. ${ }^{35}$ These have since earned him the role of expert in the history of the tragedy.

Academics have also shown an interest in the event. The tragedy has been covered in various studies on labour, social and immigrant history. One of the first of these was by Arthur Puotinen in the collection of essays The Finnish Experience in the Western Great Lakes Region: New Perspectives in $1975 .^{36}$ The most recent studies were published in the 2010s. Labor and social historians Gary Kaunonen and Aaron Goings have both examined the tragedy as part of their larger studies about the Copper Country Strike and the political activities of immigrants in the area, especially Finns. ${ }^{37}$ Linsday Hiltunen's thesis Cultural Memory and the Power of Place (2014) deals with the cultural memory of the

30 Hiltunen, Cultural Memory and the Power of Place, 104-106.

31 Wilbert B. Maki, Remembrance of a Tragedy, 1913, (sı: W.B. Maki, 1983); Arthur W. Thurner, Rebels on the Range: The Michigan Copper Miners' Strike of 19131-914, (Lake Linden, MI: John H. Forster Press, 1984); Peggy Germain, Tinsel \& Tears 2 (The Italian Hall Disaster, Calumet, Michigan), (Privately published, 1987).

32 Lawrence J. Molloy, Italian Hall: The Witnesses Speak, Great Lakes (Hubbell, MI: Great Lakes, GeoScience, 2014); Peggy Germain, False Alarm: 1913 Italian Hall Disaster and Death Certificates (Author House, 2005).

33 Deborah K. Frontiera, Living on Sisu: The 1913 Union Copper Strike Tragedy, (Bluebonnets, Boots \& Books Press, 2010).

34 Lehto, Death's Door; the second edition was published in 2013.

35 Lehto, Italian Hall.

36 Arthur Puotinen, "Copper country Finns and the strike of 1913," in The Finnish Experience in the Western Great Lakes Region: New Perspectives, ed. Michael G. Karni, Matti E. Kaups and Douglas J. Ollila, (Turku: Migration Institute, 1975); The collection also marks the beginning of ongoing collaboration between Finnish and American scholars studying Finns in the United States. See e.g. Labouring Finns: Transnational Politics in Finland, Canada, and the United States, ed. Michel S. Beaulieu, Ronald N. Harpelle and Jaimi Penney, (Turku: Institute of Migration, 2011); Finns in the United States: A History of Settlement, Dissent, and Integration, ed. Auvo Kostiainen, (East Lansing: Michigan State University Press, 2014).

37 See also Gary Kaunonen, Challenge Accepted: A Finnish Immigrant Response to Industrial America in Michigan's Copper Country, (Lansing: Michigan State University Press, 2010). 
strike and the tragedy it inflicted on the local community. A notable number of the authors mentioned above are of Finnish descent.

In 2004 the shooting of material for the documentary 1913 Massacre: A Film inspired by a Woody Guthrie Song, began. The film produced and directed by Ken Ross and Louis V. Galdieri (Dreamland Pictures LLC) came out in 2011 and has since been screened around the United States as well as in Finland. ${ }^{38}$ The documentary Red Metal: The Copper Country Strike of 1913 directed by Jonathan Silvers (Saybrook Productions LTD) premiered in December 2013 and was shown on Finnish national television a year later. ${ }^{39}$ In both of the films Woody Guthrie's song is performed, in the former by Arlo Guthrie and in the latter by Steve Earl.

\section{A Transnational Heritage Site?}

The tragedy has been commemorated in various ways including books, memoirs, films, songs, conferences, lectures, tours, concerts and even an opera. ${ }^{40}$ Yet, in spite of all the interest, there exists no permanent exhibition about the event. ${ }^{41}$ However, the Italian Hall was listed on the National Register of Historic Sites in 1980. In spite of pleas to salvage and renovate the building, The Italian Hall was pulled down in 1984. Afterwards the sandstone arch of the doorway was erected as a memorial of the tragedy at the now empty lot of the Italian Hall.

At the site there is also a marker which tells the story of the incident. The original text, which mentions the inward opening doors, was replaced in 2013 with a new text:

Michigan Historic Site, Italian Hall Tragedy

By December 1913, thousands of area copper miners had been on strike for five months. They were fighting for union recognition, safer working conditions, shorter workdays and better pay. On Christmas Eve hundreds gathered on the second floor of the Italian Hall to attend a holiday party for strikers' families. As the children filed to the stage to receive presents,

381913 Massacre: A Film inspired by a Woody Guthrie Song, accessed 7 June 2016, http://1913massacre.com/.

39 Yle, TV 1, Historia: Veristä kuparia, accessed 7 June 2016, http://yle.fi/aihe/artikkeli/2014/ 12/11/historia-verista-kuparia.

$40 \quad$ Hoagland, Unresolved; Hiltunen, Cultural Memory and the Power of Place.

41 Michigan Technological University Archives created a travelling exhibit "Turmoil \& Tragedy" with its own website for the centennial of the 1913-1914 strike: "Tumult and Tragedy: Michigan's 1913-14 Copper Strike", accessed 7 June 2016, http://www.1913strike .mtu.edu/index.html. 


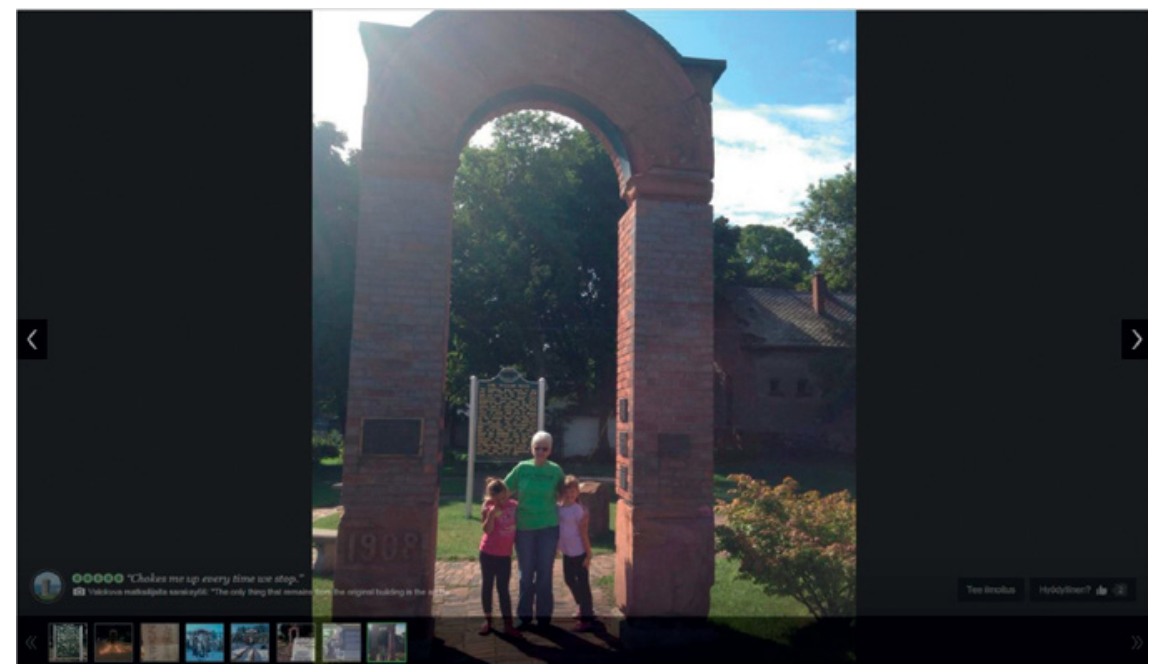

FIGURE 11.2 "Chokes me up every time we stop" commented one person on TripAdvisor after visiting the Italian Hall memorial. (Accessed 1o June, 2016, https://www.tripadvisor.com/Attraction_Review-g42038-d4557640-Reviews-Italian_Hall_Site-Calumet _Upper_Peninsula_Michigan.html.SScreenshot 4 May 2017)

someone yelled, 'Fire!' People panicked and rushed toward the exit. There was no fire. Many were trampled on the stairs. Officially seventy-three people died: more than half were children under ten. Despite a Congressional hearing and a coroner's inquest, the person whoyelled fire was never identified.

Several immigrant communities were involved in the tragedy, Finnish, Italian, Slovenian, Croatian and Polish. The marker tells the story of the tragedy, but does not list either the names of the seventy-three victims or their ethnicities. The only recognition of ethnicity is a plaque donated by the Italian American Ethnic Organization with the text 'In honor of the Italian-Americans who contributed greatly to this community'. Although the plaque is attached to the memorial arch it makes no reference to those members of the community who lost their lives in the tragedy. ${ }^{42}$ According to Lehto the reason for this is that it would raise questions and disputes about the number of victims, their names and their nationalities. Fifty-five of the victims were born in the United States, though they were identified according to the nationality of their parents. ${ }^{43}$

42 Lehto, Death's Doors, 95-97.

43 Lehto, Death's Doors, 148, 206; The Italian Hall Disaster, Calumet, Michigan, accessed 7 June 2016, http://www.genealogia.fi/emi/emizd31e.htm. 
Memory continues to travel and have new meanings attached to it. The Italian Hall memorial can be regarded as a site of 'pain and shame' as Keir Reeves and William Logan describe heritage sites that are a result of episodes which most would rather forget than remember. ${ }^{44}$ On TripAdvisor, reviewers recommend visiting the memorial to commemorate the disaster, to get acquainted with labour history and, as one reviewer notes, with 'the need for safety in all building construction safety'.45 Today it is regarded also as a more or less macabre dark heritage site and can be found in books and webpages listing examples of unsolved crimes, places of untimely death or other 'strange' or 'unusual' places. ${ }^{46}$

\section{Digital Diasporas and Diasporic Genealogy}

For dispersed migrants around the world the Internet offers various ways to connect with each other. Members of these diasporic-based online groups not only have a whole range of different sites to choose from, but their reasons to participate in these activities also vary. Michel S. Laguerre defines digital diaspora as

[a]n immigrant group or descendant of an immigrant population that uses IT connectivity to participate in virtual networks of contacts for a variety of political, economic, social, religious, and communicational purposes, that for the most part, may concern either the homeland, the host land or both, including its own trajectory abroad. ${ }^{47}$

44 William Logan and Keir Reeves, "Introduction: Remembering places of pain and shame," in Places of Pain and Shame. Dealing with Difficult Heritage, ed. William Logan and Keir Reeves, (London \& New York, Routledge, 2009), 1.

45 TripAdvisor, Italian Hall Site, Calumet, accessed 7 June 2016, https://www.tripadvisor. com/Attraction_Review-g42038-d4557640-Reviews-Italian_Hall_Site-Calumet_Upper_ Peninsula_Michigan.html.

46 Michigan's Otherside: Exploring the Strange \& Unusual in the Great Lakes State, Wicked, accessed 7 June 2016, http://michigansotherside.com/the-tragedy-at-italian-hall/; Viral Nova OMG, 25 Days of Creepy Christmas, Day 5, accessed 7 June 2016, http://www .viralnova.com/italian-hall-disaster/; Crime Magazine, America's Worst Unsolved Crime: The 1913 Italian Hall Disaster accessed 7 June 2016, http://www.crimemagazine.com/ america\%E2\%80\%99s-worst-unsolved-crime-1913-italian-hall-disaster.

47 Michel S. Laguerre, "Digital Diaspora: Definition and Models," in Diasporas in the New Media Age: Identity, Politics and Community, ed. Adoni Alonso \& Pedro J. Oiarzabal, (Las Vegas: University of Nevada Press, 2010), 50. 
Family history is one the most popular reasons to engage in history-making. ${ }^{48}$ The digital and participatory turn has meant a further increase on family history practices and what Catherine Nash (2008) refers to as diasporic genealogy, the searching for one's ancestral roots in 'the old home country' or among family members who have migrated to other parts of the world. ${ }^{49}$ In addition to searching for lost relatives and sharing family memories, people can help and assist each other in these practices on the Internet independent on where they are.

It is estimated that there are over 600,000 people in the United States who recognize their Finnish ancestry..$^{50}$ Over 4,400 of them belong to a closed Facebook group 'American Finnish people'. In addition there are Facebook pages for local Finnish American groups around the country with several hundred members in each, for example 'Finnish American Heritage Society of Cantebury, Ст' (496 likers, accessed 7 June 2016), 'Cokato Finnish American Historical Society' (426 likers, accessed 7 June 2016) and 'MN Finnish American Historical Society Duluth, MN (133 likers, accessed 7 June 2016). Most of the members of these groups are second or third generation Finns. The two most popular groups 'Finnish Genealogy' and 'Old Recipes from Our Finnish Ancestors' are closed Facebook groups dedicated to the sharing of family history and memories. 'Finnish Genealogy' was established in 2014 and the membership continues to grow ( 7,085 members, accessed 7 June 2016). The group members share personal documents, such as family photos, letters and documents, and help each other in translating texts, searching for information in parish registers or answering various enquires. The group 'Old Recipes from Our Finnish Ancestors' $(5,484$ members, accessed 7 June 2016) is a spin-off of the former group created in 2014 for the sole purpose of sharing old and new family recipes in order to 'connect and learn more about our Scandinavian and Finnish heritage, and to share recipes, memories and stories related to our roots, drawing us all closer through similar interest in our Scandinavian and Nordic heritage'. As a result of these activities all of these sites form archives consisting

48 For the United States see Roy Rosenzweig and David Thelen, Presence of the Past. Popular Uses of History in American Life, (New York \& Chichester, Columbia University Press, 1998), 21-22, 89-114; For Australia see Paul Ashton and Paul Hamilton, History at the Crossroads: Australians and the Past, (Sydney: Halstead Press, 2007), 27-28; For Finland see Pilvi Torsti, Suomalaiset ja historia, (Helsinki: Gaudeamus, 2012), 29-37, 40-51.

49 Catharine Nash, Of Irish Descent: Origin Stories, Genealogy, \& the Politics of Belonging, (Syracuse, Syracuse University Press, 2008), 15-16.

Kero, "Migration from Finland to North America," 53. 
of thousands of posts and hundreds and hundreds of photos, as well as some videos and text files.

I examine these types of online sites as certain types of archives, spontaneous archives, because they are also about selection, displaying and curation. But then again, compared to archives proper, spontaneous archives are dynamic, continuously evolving and often ephemeral. Spontaneous refers to the fact that these sites are often created at the spur of the moment. Therefore they may disappear or be removed without former notice or they may turn into long-lasting online archives, which may or may not be actively updated. Spontaneous also emphasizes the unofficial nature of these non-institutional memorial sites, in the same manner as vernacular and grassroots memorials are on occasion referred to as spontaneous shrines. ${ }^{51}$ Spontaneous archives may also be compared to independent community archives, but they do not require a sense of community to the same degree. ${ }^{52}$ People are drawn to spontaneous archives for various reasons. Spontaneous archives, similar to their counter parts spontaneous shrines, are the result of an emotional need to share private and public memories within a group to which one feels connected, even if the members of the group do not know each other.

Spontaneous archives come in numerous forms - blogs, YouTube videos, Flickr, Facebook etc. Spontaneous archives can be part of a larger audiovisual archive, which Brunow defines as 'the sum of images, sounds and narratives circulating in a specific society at a specific historical moment ${ }^{53}$ or a part of a digital archive such as YouTube, which also allows for the uploading of usergenerated material and therefore resembles archives in general. Spontaneous archives have also common features with creative archives or invented archives, where people publish user-generated contents for fun, as a fandom activity, school assignment, or private or public history and memory making, for example. ${ }^{54}$ Similar to creative and invented archives, spontaneous archives are created primarily for the user's own needs.

51 Jack Santino, "Performative Commemoratives: Spontaneous Shrines and the Public Memorialization of Death," in Spontaneous Shrines and the Public Memorialization of Death, ed. Jack Santino, (New York, Palgrave Macmillan, 2006).

52 Andrew Flinn, "Archival Activism: Independent and Community-led Archives, Radical Public History and the Heritage Professions," InterActions: UCLA Journal of Education and Information Studies, 7 (2011): xx, accessed 7 June, 2016. http://escholarship.org/uc/ item/9pt2490x.

53 Brunow, Remediating Transcultural Memory, 197.

54 Garde-Hansen, Media and Memory, 83-86. 


\section{Spontaneous Archives and Remixed Memories}

The Italian Hall tragedy continues to be commemorated and discussed on various websites and blogs. Some of these have been created by different institutions for the centennial of the Copper Country Strike $1913-1914,{ }^{55}$ by local history enthusiasts ${ }^{56}$ or political and labour organizations. ${ }^{57}$ However, most of the online discussions, sharing of post memories and commemorating takes place on public and semi-public social media sites dedicated to family, local, ethnic, migrant, or worker's history.

On blogs the event is typically commemorated through the use of both text and images. Most of the images are newspaper clippings about the tragedy and old photos which have been circulated elsewhere. But private blogs may also include family photos of family members who survived the tradegy, as well as new family photos of the descendants of the survivors. The use of images has increased immensely in recent years. Images can be used as memory tools, but also to comment on and discuss. Documentary images and family photos both function as records of the past and testify to the authenticity of the events. ${ }^{58}$

The Facebook page 'The Italian Hall Disaster - Resource Center' was created in December 2011 and had 659 members in June 2016. The page announces: 'This site is a clearinghouse for information, photos and discussion of the Italian Hall disaster of 1913. Feel free to contribute. ${ }^{59}$ The page was created and is administrated by the author of the book Death's Door, Steve Lehto. Hundreds of photos, documents and newspaper clippings have been posted on the page, some by Lehto and some by the other users of the page. Other sites have also

55 Copper Country History: History, Heritage, Memory, accessed 7 June 2016, https:// coppercountry.wordpress.com/;Finnish AmericanHistoricalArchive/FinlandiaUniversity February: 2008 Oral History Digitization Project:1913-1914Copper Strike and Italian Hall Disaster, accessed 7 June 2016, http://www.kentsgenealogy.com/finnamericanoralhistories/ CopperStrike.html; 1913-2013 Michigan Copper Miners' Strike 1913-14 Centennial, Ceremony at Italian Hall During FinnFest, accessed 7 June 2016, https://1913strike.wordpress .com/2013/06/26/ceremony-at-italian-hall-during-finnfest/.

56 Copper Country Reflections, Italian Hall Tragedy, accessed 10 June 2016, http://www .pasty.com/reflections/id228.htm; Lost in Michigan, The Italian Hall in Calumet: Michigan Historical Markers, accessed 10 June 2016, http://lostinmichigan.net/.

57 Labor and Working-Class History Association, accessed 10 June 2016, http://lawcha.org/ wordpress/2013/07/25/100-years-later-michigans-1913-14-copper-country-strike/

58 Annette Kuhn, An Everyday Magic: Cinema and Cultural Memory, (London \& New York: Tauris, 2002), 49; Van Dijck, Mediated Memories, 112-113; Brunow, Remediating Transcultural Memory, 5 .

59 Facebook, “The Italian Hall Disaster- Resource Center", accessed 10June 2016. https://www .facebook.com/The-Italian-Hall-Disaster-Resource-Center-291845417514549/?ref=br_rs 
been created on Facebook to promote other projects linked to the event, for example the documentary 1913 Massacre that has its own Facebook page with $33^{2}$ likers ${ }^{60}$ and Kaunonen's and Goings study with 95 likers. ${ }^{61}$

YouTube videos are a new medium for people to commemorate family and local history and provide thought-provoking examples of how the vernacular, institutional and commercial are mixed today. These user-generated videos are typically remixed, ${ }^{62}$ consisting of a montage of photos, archival documents, postcards, newspaper clippings etc., with a well-known song by a well-known artist playing in the background. Bruce Springsteen's song 'Youngstown' from the album 'The Ghost of Tom Joad' (1995), which tells the story of the rise and decline of this once prosperous steel town, has, for example, inspired people coming from Youngstown or similar towns to create remix videos. ${ }^{63}$ Among the twenty most-popular versions of Guthrie's song '1913 Massacre', played by Guthrie himself, his son Arlo Guthrie, Bob Dylan or by someone else on YouTube, ${ }^{64}$ there are four remix videos of the Italian Hall tragedy, which consist of Guthrie's song and a montage of photos and newspaper clippings. The most popular one of these '1913 massacre at the Italian Hall' published in 2009 by showbet had 7,658 views in June 2016, which is over a thousand more than in May 2015 when I first viewed it $\left(6,340\right.$ views). ${ }^{65}$

For some the story of the Italian Hall tragedy is about the hardships of migrant communities and workers in general while some use it to criticize capitalism and express their political views. Some use it to stress the need for safety regulations in building constructions. Others will express their astonishment about not having any knowledge of this important event, which is related to their family or local history. Many mention in their comments that although they have no personal connection to the event or had not even known about it before, they can still relate to the experiences of those who were part of the tragedy. Over a

6o Facebook, "1913 Massacre: film", accessed 10 June 2016.

61 Facebook, "About 1913-14 Michigan Copper Strike and Italian Hall Tragedy Book Project".

62 Remix is the reworking or adaptation of an existing work. The remix may be subtle, or it may completely redefine how the work comes across. It may add elements from other works, but generally efforts are focused on creating an alternate version of the original. A mashup, on the other hand, involves the combination of two or more works that may be very different from one another.

63 Anne Heimo and Kirsi Hänninen, "Participatory, Community and Spontaneous Archives and Digitally Born Cultural Heritage," Folklore Fellows' Network 47 (2015): 8-9.

64 Search words, "woody guthrie 1913 massacre" gives 3,820 hits, "1913 massacre calumet" 127 hits, "Italian hall tragedy" 2,680, and "italian hall disaster" 5, 480 (16 June 2016).

65 YouTube, "1913 massacre at the Italian Hall", accessed 16 June 2016, https://www.youtube .com/watch?v=UgrPK2 $\mathrm{CNuJg}$. 
Suodottimet -
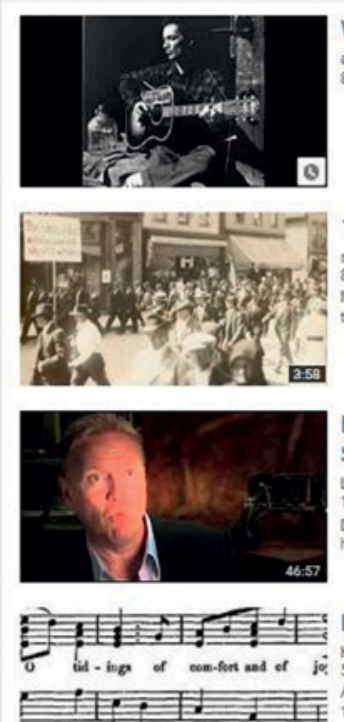

Italian Hall Disaster of 1913

Kbear586

5 vuotta sitten - 1463 näyrtökertas

A brief story surrounding the ltalian Hall disaster in Calumet. Michigan
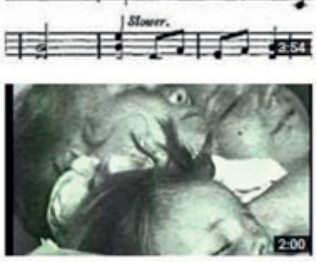

1913 massacre film to run

TV6 \& Fox UP

4 vuotta sitten $\cdot 4013$ näyttōkertas

A film about the the Italian Hall disaster will be shown

Facebook -

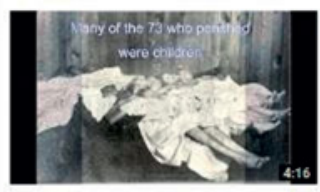

Italian Hall Disaster

\section{Karl Carter}

1 vuosi sitten - 153 näyttökertaa

1913 Massacre.

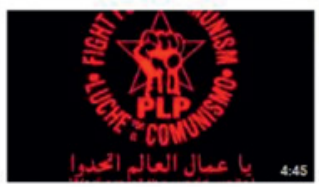

Italian Hall Massacre, 1913

PWorkers?

4 vuotta sitten - 82 näyttökertaa

Background: http://en.wikipedia.org/wiki/1913_Massacre.

FIGURE 11.3 On YouTube search words "italian hall 1913" offer a variety of different types of videos concerning the tragedy.

(Accessed 1o June, 2016, https://www.youtube.com/results?search_ query=italian+hall+1913. Screenshot 4 May 2017)

hundred years later the remediated memories of the tragedy still evoke emotive reactions and serve as an example of prosthetic memory ${ }^{66}$ at work.

66 Alison Landsberg, Prosthetic Memory: The Transformation of American Remembrance in the Age of Mass Culture, (New York: Columbia University Press, 2004), 2-3. 
However the most popular reason to participate in the commemoration of the tragedy is when it is part of one's family or local history. ${ }^{67}$ This has to do with the fact that family history practices have become immensely popular in recent years and that people trust family memories and narratives highly as historical sources - even when they contradict facts presented in other sources. Family narratives encompass strong emotional power and vernacular authority. These features make them reliable accounts of the past and worth sharing with each other. According to folklorist Robert Howard, vernacular authority 'emerges when an individual makes appeals that rely on trust specifically because they are not institutional'. ${ }^{6}$ These appeals are backed up, for instance, by tradition - or as in this case by family memories - and not by a formally instituted social formation such as a church, a media company or an academic publication.

\section{The Power of Family Memories}

On all of the sites mentioned above people will frequently mention how the tragedy relates to their family history and where and when they learned about the event. The following family story titled 'The Hundred Year Anniversary of The Italian Hall Disaster' was published by Brita Caroline, a photographer living on the Michigan Upper Peninsula on Christmas Day, 2013:

We all grew up hearing stories. It was so horrifying. Children died. DIED. ON Christmas Eve. At a Christmas party. It was too much to take in. All of those precious little children, just trying to celebrate the season amidst a time of turmoil. We saw pictures that never left our brain. We heard all about the door that opened inwards, and we all felt anger at the man who hollered, "Fire!"

For us Eskolas, it took on a whole new meaning when we grew up with our own personal story attached to it. My Grandma Ethel is my dad's mom. She is still with us today, and we cherish her dearly. She is a special, special woman. Her father, who we call Papa Hill, was there at the Italian Hall on that fateful night. When the panic set in from the call of fire, Papa Hill was about to head to the stairs too, but his older sister stopped him and gathered him and his siblings with her to wait it out by one

67 Heimo, "The 1918 Finnish Civil War Revisited".

68 Robert Glenn Howard, “Vernacular Authority: Critically Engaging 'Tradition', in Tradition in the Twenty-First Century. Locating the Role of the Past in the Present, ed. Trevor J. Blank \& Robert Glenn Howard, (Logan: Utah State University Press, 2013), 83. 
of the windows. They stood there together, the siblings, in a tight little group, listening to the horror of it all, until finally they were led to safety through the window and down a ladder. Can you imagine?? What those kids heard?? But still, they were the lucky ones. It's impossible to imagine.

Not everyone was so lucky. A lot of young children's lives ended that night. It changed the Copper Country forever. When the Hollywood producers came a few years ago, they said that they could still feel the tragedy as they walked around the desolate streets of Calumet. Something this big doesn't just go away. It changes people forever, and it becomes who you are. This is who we are up here in the Copper Country. We fully embrace it because it makes the grief a little bit easier to bear if we all bear just a little bit of it. ${ }^{69}$

Similar to this example most family stories about the event will either include the story of how and why their grandparent or other close relative survived or that they perished. The creator of the popularYouTube video mentioned above, [s]howbet, writes: 'My great grandmother said she didn't smell any smoke, and told the children to stay put, and hold her skirt. They were some of the few to survive the trampling. My Mother [name] and her three brothers didn't believe my grandma when she told this story'. Of the thirteen comments concerning the video one mentions the death of her great-grandmother and two tell why their grandparents survived: 'My grandmother was the last living survivor. She was a daughter of a copper miner. She only survived because she went back to her seat to get her new gloves her mother had just knitted. Her best friend, [name], sitting next to her, died. She was always adamant that it was a union man that yelled, 'fire' and '... What a terrible tragedy, my dad had talked about it (his parents weren't at the hall because his older sister was sick), didn't know there was a Woody Guthrie song about it. Thanks for posting!"70 One example of this type of survival story was even presented on a product review site by a person who had purchased a copy of the film Red Metal: 'My interest in viewing and then purchasing Red Metal centres around my family's history as my Dad was one of the children at the Christmas party. The story goes that an adult

69 Brita Caroline Photograph Blog, accessed 10 June 2016 http://britacarolineblog.com; I have been granted permission to publish the story with names.

70 YouTube, "1913 massacre at the Italian Hall", accessed 16 June 2016, https://www.youtube .com/watch?v=UgrPK2CNuJg. 

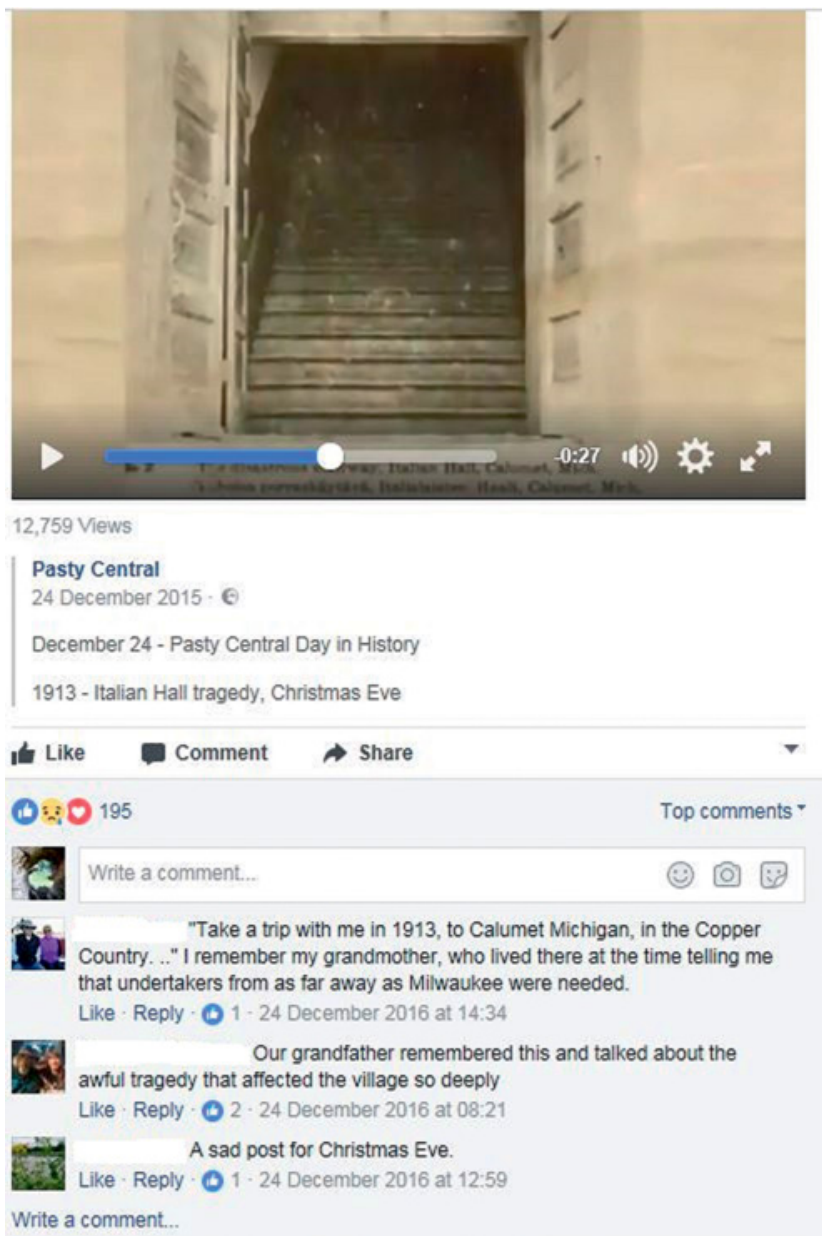

FIGURE 11.4 The tragedy continues to be discussed on various Facebook sites like on the regional site "Pasty Central" (https://www.facebook.com/PastyCentral/. Screenshot 4 May 2017)

passed him out a window to someone, thus saving his life ... ${ }^{71}$ Sometimes these survival stories leads people to ponder on the alternatives: What would it have meant for me and my family if the family members had not survived? One of

71 Shop PBs, Red Metal, Product reviews, accessed 10 June 2016, http://www.shoppbs.org/ product/index.jsp?productId=29393516. 
the blogs features a photo of the author's children with a caption: '... Imagine how [my son] might not even exist if [grandpa] would've taken those stairs.'

The names of Brita Caroline's relatives mentioned in her blog reveal that she is of Finnish descent, but she does not bring this up in her story. This is typical for most commentators. Outside the Facebook groups dedicated to Finnish-American heritage and history, people will rarely connect the event to their Finnish background. This suggests that the relevance of the story lies elsewhere.

The above examples are by no means unique or special, but illustrate how historical knowledge and memories are produced and shared (mediated) today. At first glance these family memories may seem very brief and fragmented, but actually the difference between how we share our memories online and offline does not differ much. Outside the interview situation, we rarely tell whole, coherent stories. Like Alessandro Portelli states: 'Most personal and family tales are told in pieces and episodes, when the occasion arises; we learn even the lives of our closest relatives by fragments, repetitions, hearsay. ${ }^{72}$ This is also the manner we do it online, as Henry Jenkins reminds us: 'Each of us constructs our own personal mythology from bits and fragments of information extracted from the media flow and transformed into resources through which we make sense of our everyday lives. ${ }^{73}$

\section{Conclusions}

The memory of the Italian Hall Tragedy in 1913 has been remediated for over a century in numerous forms, newspapers, journals, books, songs, autobiographies, films and, in the 200os, online. Although the memory of the disaster was forced into oblivion in the public sphere for decades, its memory has continued to be cherished in the private sphere of family. The tearing down of the Italian Hall in the 198 os followed by the centennial brought about plenty of retellings of the story. Today the memory of the tragedy also attracts tourists, especially those interested in dark tourism and dark heritage sites. A major part of the commemoration of the tragedy is institutional or academic, but the tragedy is also remembered by so-called ordinary people interested in

72 Alessandro Portelli, The Battle of Valle Giulia. Oral History and the Art of Dialogue, (Madison: The University of Wisconsin Press, 1997), 4.

73

Jenkins, Convergence Culture, 3-4. 
family and local history. Much of this remembering happens online and evokes people to share their own memories of the incident.

History and memory making and archiving are never neutral or disinterested activities. Archives can include as well as exclude, and it is often the minorities who are left out. ${ }^{74}$ Due to their small number and invisibility, Finnish immigrants are usually not accounted for in national histories of their new home countries. This applies also to those cases where they have played a significant part in the country's political history, for example in the United States and Canada. Often the experiences of immigrants go unnoticed also in their former home countries. Although more Finnish migrants died in the Italian Hall tragedy than on the Titanic, the tragedy is largely unknown in Finland.

The memory of the tragedy was never only local. The tragedy happened in a multicultural community and affected the lives of families coming from different parts of Europe. Nonetheless, much of what has been written and published about the Italian Hall tragedy has been done by people of Finnish descent, but this does not mean that they are in all cases viewing it only as a part of their family history or Finnish-American history. In the beginning of my study I assumed that spontaneous archives would offer a way for people with Finnish ancestry to bring forth their history in the United States, but my analysis shows that although much of the personal commemoration of the tragedy is intended for family and friends and the local and regional community, it offers information to anyone who has an interest in the event, for whatever reason.

The remediated memory of the Italian Hall tragedy shows that heritage no longer consists of only museum artefacts, memorials or historic sites, or that it is entirely in the hands of professionals. Due to digital technology and convergence culture people today have new kinds of possibilities to make their experiences known outside their immediate spheres to new audiences around the world, challenging in this way former notions of cultural heritage as being a product that does not change and is in need of protection, and which is controlled by experts. Instead it should be seen as a process which is dynamic, ever-evolving and ephemeral, and often curated and managed by the same people who created it or participated in the process.

74 Julia Creet, "Transnational Archives: The Canadian Case," in Journal of Aesthetics \& Culture 3, 2011; accessed 10 June 2016, doi 10.3402/jac.v3io.7216; Flinn, "Archival Activism", 3; Brunow, Remediated Transcultural Memory, 8-9. 


\section{Bibliography}

\section{Popular Books}

Bloor, Ella Reeve. We Are Many: An Autobiography of Ella Reeve Bloor. New York: International Publishers, 1940.

Frontiera, Deborah K. Living on Sisu: The 1913 Union Copper Strike Tragedy. Bluebonnets, Boots \& Books Press, 2010.

Germain, Peggy. False Alarm: 1913 Italian Hall Disaster and Death Certificates. Author House, 2005.

Germain, Peggy. Tinsel \& Tears 2 (The Italian Hall Disaster, Calumet, Michigan). Privately published, 1987 .

Hirvonen, Juuso. Michiganin kuparialue ja suomalaiset siirtolaiset. Duluth: Privately published, 1920.

Lehto, Steve. Death's Door: The Truth behind Michigan's Largest Mass Murder. Troy, MI: Momentum Books, 2006.

Lehto, Steve. Italian Hall: The Official Transcript of the Coroner's Inquest. Troy, MI: Momentum Books, 2007.

Maki, Wilbert B. Remembrance of a Tragedy, 1913. sı: W.B. Maki, 1983.

Molloy, Lawrence J. Italian Hall: The Witnesses Speak, Great Lakes. Hubbell, MI: Great Lakes, GeoScience, 2014.

Thurner, Arthur W. Rebels on the Range: The Michigan Copper Miners' Strike of 1913-1914. Lake Linden, MI:John H. Forster Press, 1984.

\section{References}

Ashton, Paul \& Hamilton, Paula, History at the Crossroads: Australians and the Past. Sydney: Halstead Press, 2007.

Brunow, Dagmar. Remediating Transcultural Memory: Documentary Filmmaking as Archival Intervention. Berlin \& Boston: De Gruyter, 2015.

Creet, Julia. "Transnational Archives: The Canadian Case." In Journal of Aesthetics \& Culture, 3, 2011. Accessed 10 June 2016, doi 10.3402/jac.v3io.7216.

Creet, Julia. "Introduction," in Memory and migration: multidisciplinary approaches to memory studies, edited by Julia Creet and Andreas Kitzmann, 3-26. Toronto: University of Toronto Press, 2011.

De Cesari, Chiara and Rigney, Anne. "Introduction: Beyond methodological nationalism." In Transnational Memory: Circulation, Articulation, Scales, edited by Chiara De Cesari and Anne Rigney, 12-41. Berlin/Boston: De Gruyter, 2014.

Erll, Astrid. "Travelling Memory." Parallax 17 (2011): 4-18. Accessed 7 June 2016. doi:10.1 080/13534645.2011.605570.

Erll, Astrid and Rigney, Ann. "Introduction: Cultural Memory and its Dynamics." In Mediation, Remediation, and the Dynamics of Cultural Memory, edited by Astrid Erll and Ann Rigney, 1-11. Berlin/Boston: De Gruyter, 2009; 
Flinn, Andrew. "Archival Activism: Independent and Community-led Archives, Radical Public History and the Heritage Professions." InterActions: UCLA Journal of Education and Information Studies, 7 (2011): 1-20. Accessed 7 June 2016. http://escholarship .org/uc/item/9pt249ox.

Garde-Hansen, Joanne. Media and Memory. Edinburgh: Edinburgh University Press, 2011.

Garde-Hansen, Joanne, Hoskins, Andrew and Reading, Anna. "Introduction.” In Save as ... Digital Memories, edited by Joanne Garde-Hansen, Andrew Hoskins and Anna Reading, 1-26. London \& New York: Palgrave McMillan, 2009.

Giarccardi, Elisa. "Introduction: Reframing Heritage in Participatory Culture." In Heritage and Social Media: Understanding Heritage in a Participatory Culture, edited by Elisa Giarccardi, 1-10, London \& New York: Routledge, 2012.

Heimo, Anne, Kapina Sammatissa. Vuoden 1918 paikalliset tulkinnat osana historian yhteiskunnallisen rakentamisen prosessia. Helsinki: Suomalaisen Kirjallisuuden Seura, 2010.

Heimo, Anne. "The 1918 Finnish Civil War Revisited: The Digital Aftermath." Folklore 57 (2014): 141-168. Accessed 7 June 2016. doi:10.7592/FEJF2014.57.heimo.

Heimo, Anne and Hänninen, Kirsi. "Participatory, Community and Spontaneous Archives and Digitally Born Cultural Heritage." Folklore Fellows' Network 47 (2015): 4-11.

Hiltunen, Linsday E. Cultural Memory and the Power of Place: One Hundred Years of Remembering the Italian Hall Tragedy and the 1913-1914 Michigan Copper Strike. Macomb: Faculty of the Department of History of Western Illinois University, 2014. Accessed 7 June 2016. http://gradworks.umi.com/15/57/1557255.html.

Hoagland, Alison K. "Unresolved: The Italian Hall Memorial in Calumet, Michigan." In Commemoration in America: Essays on Monuments, Memorialization, and Memory, edited by David Cobel and Daves Rossell. Charlottesville and London: University of Virginia Press, 2013.

Howard, Robert Glenn. “Vernacular Authority: Critically Engaging 'Tradition.”' In Tradition in the Twenty-First Century. Locating the Role of the Past in the Present edited by Trevor J. Blank \& Robert Glenn Howard, 72-99. Logan: Utah State University Press, 2013.

Jenkins, Henry. Convergence Culture: Where Old and New Media Collide. New York \& London: New York University Press, 2006.

Jenkins, Henry, Ford, Sam and Green, Joshua. Spreadable Media: Creating Value and Meaning in a Networked Culture. New York \& London: New York University Press, 2013. Kaunonen, Gary. Challenge Accepted: A Finnish Immigrant Response to Industrial American in Michigan's Copper Country. East Lansing: Michigan State University, 2010.

Kaunonen, Gary and Goings, Aaron. Community in Conflict: A Working-class History of the 1913-14 Michigan Copper Strike and the Italian Hall Tragedy. East Lansing: Michigan State University Press, 2013. 
Kauranen, Ralf, and Pollari, Mikko. "Transnational socialist imagination: The connections between Finnish socialists in the USA and Finland at the turn of the 2oth century." In Labouring Finns. Transnational Politics in Finland, Canada, and the United States, edited by Michel S. Beaulieu, Ronald N. Harpelle and Jaimi Penney, 26-49. Turku: Institute of Migration, 2011.

Kero, Reino. "Migration from Finland to North America." In Finns in the United States. A History of Settlement, Dissent, and Integration, edited by Auvo Kostiainen, 41-53. East Lansing: Michigan State University Press, 2014.

Kivisto, Peter. Immigrant Socialists in the United States: The Case of the Finns and the Left. London and Toronto: Associated University Press, 1984.

Kuhn, Annette. An Everyday Magic: Cinema and Cultural Memory. London \& New York: Tauris, 2002.

Laguerre, Michel S. "Digital Diaspora: Definition and Models." In Diasporas in the New Media Age: Identity, politics and Community, edited by Adoni Alonso \& Pedro J. Oiarzabal, 49-64. Las Vegas: University of Nevada Press, 2010.

Landsberg, Alison. Prosthetic Memory: The Transformation of American Remembrance in the Age of Mass Culture. New York: Columbia University Press, 2004.

Logan, William and Reeves, Keir. "Introduction: Remembering places of pain and shame." In Places of Pain and Shame. Dealing with Difficult Heritage, edited by William Logan and Keir Reeves, 1-14. London \& New York: Routledge, 2009.

Margry, Peter Jan \& Sánchez-Carretero, Cristina. "Introduction: Rethinking Memorialization: The Concept of Grassroots Memorials." In Grassroots Memorials. The Politics of Memorializing Traumatic Death, edited by Peter Jan Margry \& Cristina Sánchez-Carretero, 1-48. New York \& Oxford: Berghahn, 2011.

Nash, Catharine. Of Irish Descent: Origin Stories, Genealogy, \& the Politics of Belonging. Syracuse: Syracuse University Press, 2008.

Nielsen, Jakob. "The 90-9-1 Rule for Participation Inequality in Social Media and Online Communities." Nielsen Norman Group, 2006. Accessed 7 June 2016. http://www .nngroup.com/articles/participation-inequality/.

O'Reilly, Timothy. "What is Web 2.o? Design Patterns and Business Models for the Next Generation of Software." Oreilly (2005). Accessed 7 June 2016. http://www.oreilly .com/pub/a/web2/archive/what-is-web-20.html.

Portelli, Alessandro. The Battle of Valle Giulia. Oral History and the Art of Dialogue. Madison: The University of Wisconsin Press, 1997.

Puotinen, Arthur. "Copper country Finns and the strike of 1913." The Finnish Experience in the Western Great Lakes Region: New Perspectives, edited by Michael G. Karni, Matti E. Kaups and Douglas J. Ollila, 143-153. Turku: Migration Institute, 1975.

Rosenzweig, Roy and Thelen, David. Presence of the Past. Popular Uses of History in American Life. New York \& Chichester: Columbia University Press, 1998. 
Santino, Jack. "Performative Commemoratives: Spontaneous Shrines and the Public Memorialization of Death." In Spontaneous Shrines and the Public Memorialization of Death, edited by Jack Santino, 294-319. New York: Palgrave Macmillan, 2006.

Smith, Laurajane. Uses of Heritage. Oxon: Routledge, 2006.

Torsti, Pilvi. Suomalaiset ja historia. Helsinki: Gaudeamus, 2012.

Van Dijck, José. Mediated Memories in the Digital Age. Palo Alto, CA: Stanford University Press, 2007.

Van Dijck, José. The Culture of Connectivity: A Critical History of Social Media. Oxford: Oxford University Press, 2013.

Wargelin, Raymond Alvar. "Response" to Puotinen, Arthur "Copper country Finns and the strike of 1913." In The Finnish Experience in the Western Great Lakes Region: New Perspectives, edited by Michael G. Karni, Matti E. Kaups and Douglas J. Ollila. Turku: Migration Institute, 1975, 153-155. 